\title{
Comparing the metallic elemental compositions of Kelp Gull Larus dominicanus eggs and eggshells from the Swartkops Estuary, Port Elizabeth, South Africa
}

J D van Aswegen, L Nel, NA Strydom, Karen Minnaar, Henrik Kylin and Hindrik Bouwman

The self-archived postprint version of this journal article is available at Linköping University Institutional Repository (DiVA):

http:// urn.kb.se/ resolve?urn=urn:nbn:se:liu:diva-153893

N.B.: When citing this work, cite the original publication.

van Aswegen, JD, Nel, L, Strydom, NA, Minnaar, K., Kylin, H., Bouwman, H., (2019), Comparing the metallic elemental compositions of Kelp Gull Larus dominicanus eggs and eggshells from the Swartkops Estuary, Port Elizabeth, South Africa, Chemosphere, 221, 533-542.

https:// doi.org/ 10.1016/j.chemosphere.2019.01.013

Original publication available at:

https:// doi.org/ 10.1016/j.chemosphere.2019.01.013

Copyright: Elsevier

http://www.elsevier.com/

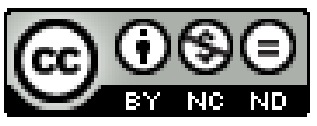


Comparing the metallic elemental compositions of Kelp Gull Larus dominicanus eggs and eggshells from the Swartkops Estuary, Port Elizabeth, South Africa

J.D. van Aswegen ${ }^{a}$, L. Nele,b, N.A. Strydom ${ }^{b}$, K. Minnaara, H. Kylin ${ }^{a, c}$, H. Bouwman ${ }^{a}$

a Research Unit: Environmental Sciences and Management, North-West University, Potchefstroom, South Africa

b Department of Zoology, Nelson Mandela University, Port Elizabeth, South Africa

c Department of Thematic Studies - Environmental Change, Linköping University, Linköping, Sweden.

*Address correspondence to: duanvaswegen@gmail.com 


\section{ABSTRACT}

Metals attributed to pollution may increase their concentrations above the geological background and pose toxic challenges towards humans and biota. We analysed sixteen Kelp Gull eggs and eggshells for 30 metallic elements from the Swartkops Estuary (SE), an important recreational, industrial, and ecological asset for Port Elizabeth, the region, and South Africa. Mean concentrations for eggshell and egg content for $\mathrm{Hg}$ was 0.02 and 0.4 $\mathrm{mg} / \mathrm{kg} \mathrm{dm}$, Cr was 4 and $18 \mathrm{mg} / \mathrm{kg} \mathrm{dm}$ (the highest yet recorded for any gull or tern egg), for Zn 2.1 and $62 \mathrm{mg} / \mathrm{kg} \mathrm{dm}$, for Sr 880 and $12 \mathrm{mg} / \mathrm{kg} \mathrm{dm}$, for $\vee 170$ and $1.3 \mathrm{mg} / \mathrm{kg} \mathrm{dm}$, and for Co 1.7 and $0.002 \mathrm{mg} / \mathrm{kg} \mathrm{dm}$, respectively. Zink, Se, and Hg, increased on a dry-mass basis from sediment via small fish to gull egg content, indicating bioaccumulation. No effect on eggshell thickness was seen. We also determined that eggshell concentrations cannot be used as a proxy for egg content concentrations. Mercury, Cr, V, Co, and Zn were elements we identified as potentially problematic that require source identification and mitigation. Further research into other high-trophic animals such as herons, egrets, cormorants, and otters in the SE system is proposed.

Keywords: Laridae, mercury, chromium, copper, zinc, vanadium, cobalt, Indian Ocean 


\section{Introduction}

The addition of toxic compounds to the environment from increasing recreational, residential, and industrial activities places more stress on receiving ecosystems (Martin \& Randal, 1987). Once pollutants such as metals and persistent organic pollutants enter aquatic ecosystems, they are difficult, if not impossible, to remove (UN Environment, 2018) and can subsequently contaminate food webs. When pollution-associated metallic elements increase in sediment or water, their toxicity can also increase, possibly affecting humans and organisms (Burger \& Gochfeld, 2003; Burger \& Gochfeld, 2007; Pizzol et al., 2011; Suiçmez et al., 2006). The concentrations of metallic elements in sediment can act as an indicator of exposure and possible accumulation by sediment-associated organisms. The accumulation in organisms at lower trophic levels may subsequently be biomagnified by and affect higher tropic-level organisms (Burger \& Gochfeld, 2000; Dauwe et al., 1999; Nel et al., 2015).

Metallic element concentrations elevated above their natural background within the ocean have become a global problem because organisms such as fish, marine mammals, and birds can be negatively affected (Klaassen \& Watkins, 2015; Suiçmez et al., 2006). Because authorities, researchers, and the public are concerned about the health of polluted ecosystems as well as food safety, bioindicators such as animals can be used for more than just scientific importance as it can inform policy and mitigation measures required (Burger et al., 2009).

Birds are good bioindicators because different species and guilds occupy different trophic levels, proving a measure of trophic bioaccumulation of pollutants (Burger \& Elbin, 2015a, Burger \& Elbin, 2015b; Mansouri et al., 2012a). The concentrations of pollutants within a bird can be externalised via, amongst others; feathers, eggs, glandular oil, and excreta (Burger \& Elbin, 2015a; Burger \& Elbin, 2015b; Burger \& Gochfeld, 2003; Dauwe et al., 1999; Mansouri et al., 2012a). Eggs, oil, and feathers can therefore be a non-lethal (to adults) method of assessing pollutants such as metallic elements within the environment and the body of the bird (Bond \& Lavers, 2011; Dauwe et al., 1999; Peck et al., 2016). Literature also suggests that eggshells of certain species can be used to infer those of egg contents for certain nonessential elements (cadmium, lead, arsenic and mercury), providing the opportunity to use discarded eggshells, thereby reducing the effects on bird populations (Ayaş, 2007; Dauwe et al., 1999; Hashmi et al., 2015).

The Swartkops River (South Africa) flows through an urbanised area where it forms part of the Swartkops Estuary (SE; Fig. 1). The SE is situated approximately $15 \mathrm{~km}$ north of Port Elizabeth on the coast of the Indian Ocean (Lord \& Thompson, 1988; Martin \& Baird, 1987). The SE is a recreational asset to people, and an ecological asset to many species of birds and fish (Martin \& Randal, 1987). Even though the SE plays an important 
environmental role, it is under considerable pressure from increasing development (Baird et al., 1988; Wallace et al., 1984). The area surrounding the SE is highly urbanised with municipal areas such as Uitenhage, Despatch, KwaNobuhle, Ibhayi and the northern part of Port Elizabeth (Binning \& Baird, 2001; Odume, 2014). The SE's water quality is influenced by agricultural run-off of pesticides and fertilizers, wastewater treatment plants, tanneries, a carbon-black factory, automobile and auto parts factories, and other anthropogenic activities (Eggleton \& Thomas, 2004; Lord \& Thompson, 1988; Odume, 2014; Suiçmez et al., 2006). These sources all have the potential to release metallic elements into the environment via improperly treated wastewater, industrial processes, and run-off from waste and polluted soils. Binning \& Baird (2001) concluded that the highest concentration of metallic elements entering the SE was from run-off, industries, and informal settlements along the banks of the river. Analyses of sediment, crustaceans, and fish from the SE indicated that cobalt (Co), chromium (Cr), Hg, strontium (Sr), uranium (U), vanadium (V) and zinc ( $\mathrm{Zn}$ ) in the SE might pose risk as the concentrations approached or exceeded norms of safety for human intake (see Nel et al., 2015). These elements are also listed in the substance priority list (ATSDR, 2017).

This study focuses on the Kelp Gull Larus dominicanus (Laridae) found throughout many parts of the southern hemisphere (Crawford et al., 1982; Crawford et al., 1997; Sepulveda \& Gonzalez-Acuna, 2014; Whittington et al., 2009; Whittington et al., 2016). They occur along the coast of South Africa where they are common - their conservation status is Least Concern (IUCN, 2016). They capture live prey but are also scavengers, feeding on food scraps such as fish offal and discards from waste dumps (Nel et al., 2015; Sepulveda \& Gonzalez-Acuna, 2014), making them susceptible to uptake of metals via their food (Ayaş, 2007; Mansouri et al., 2012b) that can be monitored using their eggs.

The aim of this study was to determine the metallic element concentrations in Kelp Gull eggs, comparing the concentrations with published levels of concern, and to assess whether the shells can be used as a proxy for pollutants contained in the egg contents, thereby negating the need to collect potentially viable eggs by sampling shells of hatched eggs only. As far as we are aware, this would be the first study of metallic elements in egg contents and eggshells of gulls from anywhere in the southern hemisphere.

\section{Materials and methods}

\subsection{Ethical approval}

The necessary permits needed for the collection of freshly laid eggs were obtained from the Department of Economic Development, Environmental Affairs and Tourism, Eastern 
Cape (Permit No. CRO 124/12CR). Bird egg collection was approved by the ethics committee of the North-West University (NWU) (NWU-00055-07-S3).

\subsection{Sampling}

Kelp Gulls breed in colonies on sand islands in the SE (Fig. 1). Kelp Gulls lay one to four eggs, usually two to three (Hockey et al., 2005). Sixteen eggs were collected from eight nests from a large breeding colony on a sand island in the mouth of the SE (Fig. 1) during the Austral spring of 2012. If more than two eggs were available per nest, the "oldest" eggs were chosen due to size as the smallest egg is expected to be laid last (Quinn, 2010). The eggs were covered with pre-cleaned aluminium foil, placed on ice, and frozen on the same day at $-20^{\circ} \mathrm{C}$ until analysis (Nel et al., 2015).

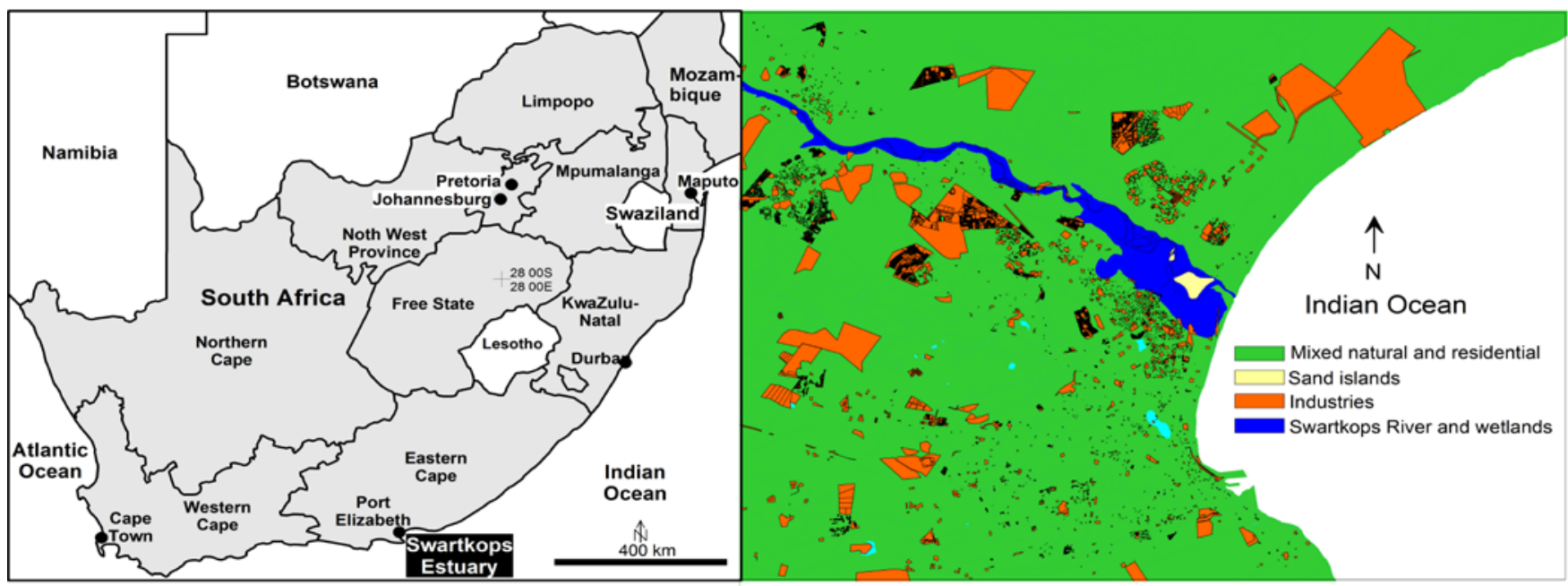

Fig. 1. Location of the Swartkops Estuary on the coast of South Africa (left), and a representation of residential and industrial factors that can influence the Swartkops Estuary, right.

\subsection{Sample treatment and analysis}

In the laboratory, the eggs were carefully rinsed with deionised water to remove any adhered materials from the shell. The eggs were divided into egg contents and eggshells. The mass of each sub-sample was determined before ultrasonic homogenising. Between every sample, the probe of the homogeniser was thoroughly washed with warm water and soap, then, rinsed in sequence with double-distilled water, 96\% ethanol, acetone, and hexane. The samples were stored in separate pre-cleaned high-density polyethylene (HDPE) $50 \mathrm{~mL}$ centrifuge tubes, freeze-dried, and powdered for further analysis. Eggshells were washed to separate the membrane from the eggshell (since it can have an effect on 
the eggshell thickness measurments and metallic element concentration). The eggshells were left for three months to air dry and then measured with a digital calliper (Kroeplin B2R20S) accurate to $0.01 \mathrm{~mm}$.

Content and shell samples, as well as a standard reference material (SRM 1944) were analysed for 30 metallic elements, using EPA 3050B for inductively coupled plasma mass spectrometry (ICP-MS) analyses, by Eco-Analytica at the North-West University. Each sample was acid- and heat-digested using 65\% nitric acid, 50\% hydrogen peroxide, and 33\% hydrochloric acid (all reagent grade; Associated Chemical Enterprises). An Agilent 7500 CE ICP-MS fitted with a Micromist-type nebulizer and a standard quartz chamber was used, optimised with a solution containing lithium $(\mathrm{Li})$, yttrium $(\mathrm{Y})$, cerium $(\mathrm{Ce})$, and thallium (TI) $(1 \mu \mathrm{g} / \mathrm{L})$ to reduce interference $(\leq 1.5 \%)$.

External calibrations were with ULTRASPkEC-certified multi-element standard solutions with elements at different, certified, concentrations (De Bruyn Spectroscopic Solutions). Calibration series standards were run separately for content and shell samples. Standard reference material concentrations were within $25 \%$ of certified values. Concentrations are expressed as $\mathrm{mg} / \mathrm{kg}$ dry mass ( $\mathrm{dm})$.

\subsection{Statistical analysis}

Summary statistics and comparisons were done using GraphPad Prism 7.04 (www.graphpad.com). We used linear regression of elemental concentrations between shells (log-transformed) and contents (normally distributed data) to investigate whether elemental concentrations in the contents can be predicted from the shell. We used each egg as an individual sample for statistical analysis as each embryo is exposed to the metals inside each egg as 16 individual exposures. Multivariate comparisons of the profiles ('fingerprints') of egg contents and eggshells were done using PC-Ord version 6.20 (MjM Software Design, www.pcord.com). The concentrations were relativised per element to compensate for the large concentration differences. Non-metric multidimensional scaling (NMS) was used, with Sørensen as the distance measure. A maximum of four axes were allowed with 200 maximum iterations, random starting conditions, and 50 runs with real data. Fifty runs with randomised data were done to stress test the final ordination. 


\section{Results}

3.1 Elemental concentrations and associated hazards

All elements had quantifiable concentrations in all samples (Table 1 for a summary of comparative data, and Table S1 in supplementary materials for summary statistics arranged by increasing \%CV values for egg contents). Although 30 elements were analysed, we concentrate on $\mathrm{Cr}, \mathrm{Zn}, \mathrm{Co}, \mathrm{V}, \mathrm{Sr}, \mathrm{U}$, and $\mathrm{Hg}$ in the $\mathrm{SE}$, due to concentrations posing potential risks found in fish and sediment (based on the findings of Nel et al., 2015). 
Table 1: Comparison of concentrations ( $\mathrm{mg} / \mathrm{kg} \mathrm{dm}$ ) found in literature and from our own data for 18 elements in gull and tern egg contents and eggshells, as well as concentrations in sediment, mud prawn and fish from Swartkops Estuary.

\begin{tabular}{|c|c|c|c|c|c|c|c|c|c|c|c|c|c|c|c|c|c|c|c|c|c|c|}
\hline Species & & Year & Place & $\mathrm{v}$ & Cr & $\mathrm{Mn}$ & Co & $\mathrm{Ni}$ & $\mathrm{Cu}$ & $\mathrm{Zn}$ & As & Se & Sr & Mo & $\mathbf{A g}$ & Cd & Sb & $\mathrm{Hg}$ & TI & $\mathrm{Pb}$ & U & Reference \\
\hline Arctic tern & & 2008 & Canada & & & & & & & & & & & & & & & 2.11 & & & & Akearok et al., 2010 \\
\hline Arctic tern & & 2004-2005 & Canada & & & & & & & & & & & & & & & 1.15 & & & & Peck et al., 2016 \\
\hline Bridled Tern & & 2002 & Hong Kong & 0.096 & 1.949 & 2.636 & 0.026 & & 3.92 & 47.62 & 1.384 & 4.386 & 1.966 & & 0.021 & 0.002 & 0.006 & 0.562 & 0.001 & 0.01 & & Lam et al., 2005 \\
\hline Bridled Tern & & 2011 & Iran & 0.096 & & & 0.009 & 0.055 & & & 0.076 & 1.082 & & & & 0.004 & & & & 0.286 & & Khademi et al., 2015 \\
\hline Bridled Tern & & 2012 & Persian Gulf & 0.129 & & & & & & & & & & & & & & & & & & Avazpour et al.. 2014 \\
\hline Common tern & & 2000 & USA & & 0.045 & 2.29 & & & & & 0.195 & 2.046 & & & & 0.004 & & 1.241 & & 0.164 & & Burger, 2002 \\
\hline Common tern & & 2010-2012 & Poland & & & & & & & & & & & & & & & 1.2394 & & & & Grajewska et al., 2015 \\
\hline Common tern & & $2000-2002$ & USA & & 0.1077 & 2.499 & & & & & 0.26133 & 2.5167 & & & & 0.006 & & 1.0463 & & 0.0953 & & Burger \& Gochfeld, 2003 \\
\hline Forster's tern & & 2000 & USA & & 0.028 & 1.702 & & & & & 0.19 & 1.688 & & & & 0.002 & & 1.939 & & 0.056 & & Burger, 2002 \\
\hline Lesser Crested tern & & 2011 & Iran & & 0.088 & & 0.009 & 0.038 & & & 0.051 & 1.133 & & & & 0.006 & & & & 0.181 & & Khademi et al., 2015 \\
\hline Lesser Crested tern & & 2012 & Persian Gulf & 0.03 & & & & & & & & & & & & & & & & & & Avazpour et al., 2014 \\
\hline Sandwich tern & & 2010-2012 & Poland & & & & & & & & & & & & & & & 1.1542 & & & & Grajewska et al., 2015 \\
\hline Whiskered Tern & & 2008 & Iran & & & & & & & & & & & & & & & 0.433 & & & & Aliakbari et al., 2010 \\
\hline White-cheecked Tern & & 2012 & Persian Gulf & 0.01 & & & & & & & & & & & & & & & & & & Avazpour et al., 2014 \\
\hline Black-tailed Gull & $\mathscr{\varrho}$ & 2008 & South Korea & & & 1.99 & & & 2.67 & 73.4 & & & & & & 0.31 & & & & 0.92 & & Kim \& Oh 2014 \\
\hline Black-tailed Gull & 总 & $1999-2001$ & Japan, & 0.041 & 0.78 & 1.82 & 0.043 & & 4.14 & 65.3 & & 3.3 & 21.3 & 0.237 & 0.008 & 0.021 & 0.03 & 0.38 & 0.012 & 0.023 & & Agusa et al., 2005 \\
\hline Glaucous Gull & ઠิ & 2004-2005 & Canada & & & & & & & & & & & & & & & 1.63 & & & & Peck et al., 2016 \\
\hline Glaucous-winged Gull & 嵒 & 2005 & USA & & 0.248 & 1.08 & & & & & 0.126 & 1.57 & & & & 0.0841 & & 0.703 & & 0.107 & & Burger et al., 2009 \\
\hline Great Black-backed Gull & & 2000 & USA & & 0.021 & 1.651 & & & & & 0.1 & 1.543 & & & & 0.005 & & 0.43 & & 0.227 & & Burger, 2002 \\
\hline Great Black backed Gull & & 2012 & USA & & 0.0553 & & & & & & 0.159 & 2.164 & & & & 0.0045 & & 1.049 & & 0.0627 & & Burger \& Elbin, 2015a \\
\hline Great Black backed Gull & & 2013 & USA & & 0.0963 & & & & & & 0.0982 & 1.864 & & & & 0.0032 & & 0.504 & & 0.26 & & Burger \& Elbin, 2015a \\
\hline Great Black-backed Gull & & 2012 & USA & & 0.0055 & & & & & & 0.159 & 2.164 & & & & 0.0045 & & 1.049 & & 0.0627 & & Burger \& Elbin, 2015a \\
\hline Herring Gull & & 2012 & USA & & 0.0852 & & & & & & 0.0574 & 1.822 & & & & 0.0053 & & 0.708 & & 0.138 & & Burger \& Elbin, 2015a \\
\hline Herring Gull & & 2000 & USA & & 0.11 & 1.622 & & & & & 0.126 & 1.836 & & & & 0.005 & & 0.419 & & 0.273 & & Burger, 2002 \\
\hline Herring Gull & & 2013 & USA & & 0.0164 & & & & & & 0.0497 & 1.323 & & & & 0.0005 & & 0.229 & & 0.244 & & Burger \& Elbin, 2014 \\
\hline Herring Gull & & 2010-2012 & Poland & & & & & & & & & & & & & & & 0.56 & & & & Grajewska et al., 2015 \\
\hline Herring Gull & & 2012 & USA & & 0.0852 & & & & & & 0.00574 & 1.822 & & & & 0.0053 & & 0.706 & & 0.138 & & Burger \& Elbin, 2015a \\
\hline Ivory Gull & & 2004-2005 & Canada & & & & & & & & & & & & & & & 6.4 & & & & Peck et al., 2016 \\
\hline Ross's Gull & & 2004-2005 & Canada & & & & & & & & & & & & & & & 0.96 & & & & Peck et al., 2016 \\
\hline Sabine's Gull & & 2004-2005 & Canada & & & & & & & & & & & & & & & 0.53 & & & & Peck et al., 2016 \\
\hline Thayer's Gull & & 2004-2005 & Canada & & & & & & & & & & & & & & & 1.02 & & & & Peck et al., 2016 \\
\hline Kelp Gull & & 2012 & South Africa & 1.3 & 18 & 1.4 & 0.02 & 0.12 & 4.8 & 62 & 0.26 & 2 & 12 & 0.25 & 0.28 & 0.0015 & 0.05 & 0.38 & 0.00022 & 0.014 & 0.000084 & This study \\
\hline Bridled Tern & & 2002 & Hong Kong & & 0.241 & 1.112 & 0.398 & & 1.235 & 2.351 & 0.397 & 15.58 & 289.6 & & & 0.002 & & 0.004 & 0.002 & 0.06 & & Lam et al., 2005 \\
\hline Bridled Tern & & 2012 & Persian Gulf & 0.45 & & & & & & & & & & & & & & & & & & Avazpour et al., 2014 \\
\hline Common tern & & 2010-2012 & Poland & & & & & & & & & & & & & & & 0.0536 & & & & Grajewska et al., 2015 \\
\hline Lesser Crested tern & & 2012 & Persian Gulf & 0.12 & & & & & & & & & & & & & & & & & & Avazpour et al., 2014 \\
\hline Sandwich tern & $\overline{\bar{\Phi}}$ & 2010-2012 & Poland & & & & & & & & & & & & & & & 0.0501 & & & & Grajewska et al., 2015 \\
\hline Whiskered Tern & बू̆ & 2008 & Iran & & & & & & & & & & & & & & & 0.0026 & & & & Aliakbari et al., 2010 \\
\hline White-cheecked Tern & & 2012 & Persian Gulf & 0.05 & & & & & & & & & & & & & & & & & & Avazpour et al., 2014 \\
\hline Black-tailed Gull & & 2008 & South Korea & & & 2.76 & & & 2.8 & 53.6 & & & & & & 0.45 & & & & 3.1 & & Kim \& Oh 2014 \\
\hline Black-tailed Gull & & $1999-2001$ & Japan & 0.011 & 0.4 & 1.13 & 0.74 & & 0.535 & 0.778 & & 0.42 & 1650 & 0.025 & 0.005 & 0.013 & 0.03 & & 0.023 & 0.061 & & Agusa et al., 2005 \\
\hline Kelp Gull & & 2012 & South Africa & 170 & 3.8 & 0.68 & 1.7 & 1.4 & 13 & 2.1 & 0.26 & 0.3 & 880 & 0.1 & 0.5 & 0.0004 & 0.032 & 0.02 & 0.00017 & 0.022 & 0.000057 & This study \\
\hline Sediment*t & & 2012 & South Africa & 10 & $\frac{22}{22}$ & 84 & 3 & 7 & 7 & 28 & $\frac{5}{5}$ & $\frac{1}{1}$ & 300 & $\frac{1}{1}$ & 0.003 & 0.1 & 0.2 & 0.01 & 0.1 & 11 & 1 & Nel et al., 2015 \\
\hline Knysna sand goby* & & 2012 & South Africa & & 10 & 10 & 0.2 & 0.5 & 2.8 & 110 & 2.4 & 1.7 & 52 & & & 0.07 & & 0.02 & 0.02 & 0.4 & & Nel et al., 2015 \\
\hline Estuarine round herring* & 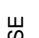 & 2012 & South Africa & & 5.2 & 14 & 0.5 & 0.7 & 4.5 & 67 & 6.6 & 1.7 & 240 & & & 0.05 & & 0.02 & 0.03 & 0.5 & & Nel et al., 2015 \\
\hline Mud prawn* & & 2012 & South Africa & 2 & 8 & 100 & 1 & 2 & 150 & 77 & 7 & 4 & 700 & 1 & 2 & 0.2 & 0.2 & 0.2 & 0.04 & 2 & 0.1 & Nel et al., 2015 \\
\hline Garrick liver* & & 2012 & South Africa & & 26 & 5 & 2 & 2 & 2000 & 200 & 10 & 100 & 3 & & & 1 & & 1 & 0.1 & 1 & & Nel et al., 2015 \\
\hline
\end{tabular}

*Dry mass and means from original (Nel et al., 2015) data. 
Chromium: Mean $\mathrm{Cr}$ concentrations of 4 and $18 \mathrm{mg} / \mathrm{kg} \mathrm{dm}$ were found in eggshells and egg contents of the Kelp Gull (Table 1). The highest concentrations recorded in eggshell and content were 6.4 and $20 \mathrm{mg} / \mathrm{kg} \mathrm{dm}$, respectively (Table S1). This Cr concentration was the highest found in literature for any larid egg or shell (Table 1). The \%CV of $\mathrm{Cr}$ in egg contents was low at $8 \%$, compared with other elements (Table S1).

Zinc: Mean Zn concentration of 2.1 and $62 \mathrm{mg} / \mathrm{kg} \mathrm{dm}$ was found for eggshells and egg content of the Kelp Gull, respectively (Table 1 ). A relatively low $\%$ CV of $12 \%$ was found for egg content (Table S1).

Cobalt: Mean Co concentrations of 1.7 and $0.002 \mathrm{mg} / \mathrm{kg} \mathrm{dm}$ were quantified in eggshells and egg contents of the Kelp Gull, respectively (Table 1). A relatively low \%CV of $8.2 \%$ were found for eggshells concentrations, in comparison to other elements (Table S1).

Vanadium: Mean concentrations of $V$ at 170 and $1.3 \mathrm{mg} / \mathrm{kg} \mathrm{dm}$ were found in eggshell and egg content of the Kelp Gull, respectively (Table 1), with a relatively low \%CV of $19 \%$ for eggshells (Table S1). Higher concentrations of $V$ were associated with lower concentrations of $\mathrm{Cr}$ in eggshell $(p=0.0232)$, respectively (Table S1). Higher concentrations of $\mathrm{Cr}(18 \mathrm{mg} / \mathrm{kg} \mathrm{dm})$ occurred in egg contents, coinciding with higher concentrations of $\mathrm{V}$ (170 mg/kg dm) in eggshells, suggesting antagonism (Avazpour et al., 2014).

Strontium: Mean Sr concentrations of 880 and $12 \mathrm{mg} / \mathrm{kg} \mathrm{dm}$ were determined for eggshells and egg contents, respectively (Table 1). Eggshell concentrations from this study ranged between 360-1299 $\mathrm{mg} / \mathrm{kg} \mathrm{dm}$ with a relatively low \%CV of 33\% (compared with the other elements) (Table S1). There was a statistically significant positive linear regression between $\mathrm{Ca}$ and $\mathrm{Sr}$ within eggshells (Fig. $2 \mathrm{~h} ; \mathrm{p}=0.0006$ ), but not in contents.

Uranium: Mean concentrations of 0.00006 and $0.00008 \mathrm{mg} / \mathrm{kg} \mathrm{dm}$ were found in eggshells and egg contents of the Kelp Gull, respectively (Table 1). A relatively low \%CV of $31 \%$ and $9 \%$ were found for eggshells and egg content, respectively, when compared with the other elements (Table S1).

Mercury: Mean $\mathrm{Hg}$ concentrations of 0.015 and $0.375 \mathrm{mg} / \mathrm{kg} \mathrm{dm}$ were found in eggshells and egg contents, respectively (Table 1 ). The highest $\mathrm{Hg}$ concentration we determined within egg content was $2.1 \mathrm{mg} / \mathrm{kg} \mathrm{dm}$, with a relatively high \%CV of 130\% (Table S1).

3.3 Associations between elemental concentrations in egg contents and eggshells 

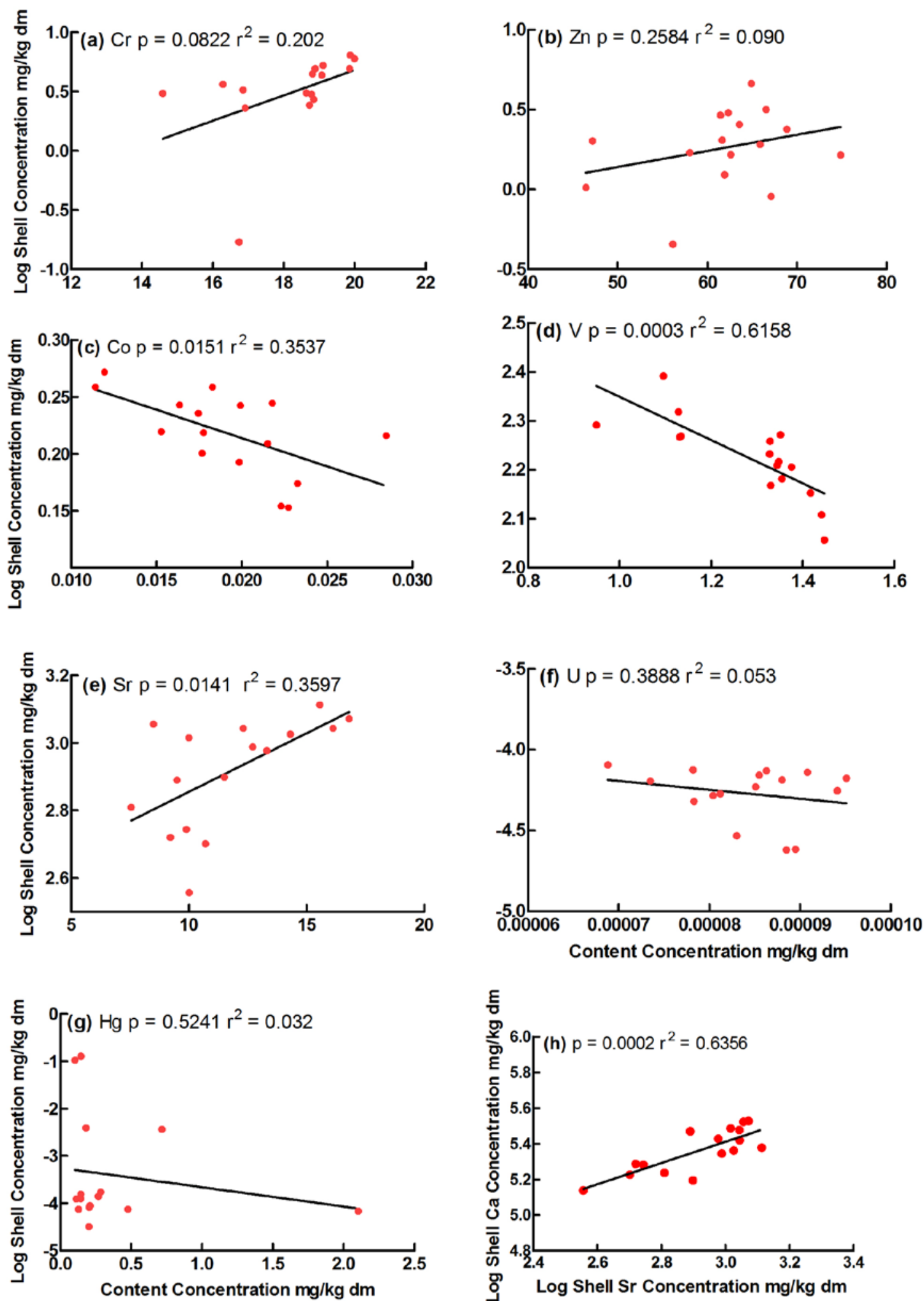

Figure 2: Linear regressions representing log-transformed shell concentration versus content concentration ( $\mathrm{mg} / \mathrm{kg} \mathrm{dm}$ ) for chromium (a), zinc (b), cobalt (c), vanadium (d), strontium (e), uranium ( $f$ ), and mercury $(g)$. The linear regression for Sr shell concentration versus Ca shell concentration ( $\mathrm{mg} / \mathrm{kg} \mathrm{dm}$ ) is presented in (h). 
The content concentrations were normally distributed while the shell concentrations had to be log-transformed. A positive but not significant linear association between concentrations in egg contents and eggshells was found for $\mathrm{Cr}$ (Fig. 2a; $\mathrm{p}=0.822$ ) and $\mathrm{Sr}$ (Fig. 2c; $p=0.0141$ ). Vanadium (Fig. 2d; $p=0.0003$ ) and Co (Fig. 2e; $p=0.0151$ ) had significant negative linear regressions. Although the regression for $\mathrm{Zn}$ was not statistically significant (Fig. $2 b ; p=0.2584$ ), a positive association between egg contents and eggshells was apparent. Uranium and $\mathrm{Hg}$ also had negative linear associations (Fig. $2 \mathrm{f}$ and $2 \mathrm{~g}$ ) which were not statistically significant. Care should be taken when interpreting 30 regressions, as some might be spurious, at $p<0.05$.

\subsection{Eggshell thinning}

The thinnest eggshell measured was $0.25 \mathrm{~mm}$; the thickest was $0.31 \mathrm{~mm}$. This is a $19 \%$ difference between the thickest and thinnest shells. Linear regressions showed no significant $(p<0.05)$ associations between elements in both egg contents and eggshells, with eggshell thickness for any of the 30 elements analysed. However, since 60 regressions were run, one out of twenty regressions (5\%) may be spurious and care should be taken when interpreting the results.

\subsection{Relative compositional profiles of elements in eggshells and egg contents}

The NMS ordination (Fig. 3), showing the relative compositions ('fingerprints') between eggshell and egg contents needed only two of the four allowed dimensions after 49 iterations to achieve a final stress of 6.15 , with a final instability of 0.0000 . The final instability means that after 49 iterations, no further improvement will be achieved with more iterations. The stress value shows the measure of alteration needed to project the ordinations within only two dimensions. A final stress value between five and ten provides an excellent representation of the relationships between samples (McCune \& Grace 2002). Individual samples that are more closely grouped together are more similar and elements grouped further from each other are less similar, based on their relative proportional composition.

The two convex hulls indicate the separation of metallic elements in association with eggshells and egg content ('fingerprints' are distinct). Egg contents had relatively higher relative compositions of $\mathrm{HG}, \mathrm{Rb}, \mathrm{Zn}$, and $\mathrm{B}$, while the contents had relatively higher compositions of $\mathrm{Co}, \mathrm{Pd}, \mathrm{Ni}, \mathrm{Cu}$, and $\mathrm{Ba}$. Lead and $\mathrm{Ag}$ ordinated perpendicular to axis 1, indicating no association with either matrix. Lead and Ag also ordinated opposite each other, indicating an increase in relative composition of one is concomitant with a decrease of the other. These two elements, and $\mathrm{Cd}$ to a lesser extent, seem to be contributing the most 
towards axis 2 (Fig. 3), irrespective of their relative concentrations in eggshells or egg contents.

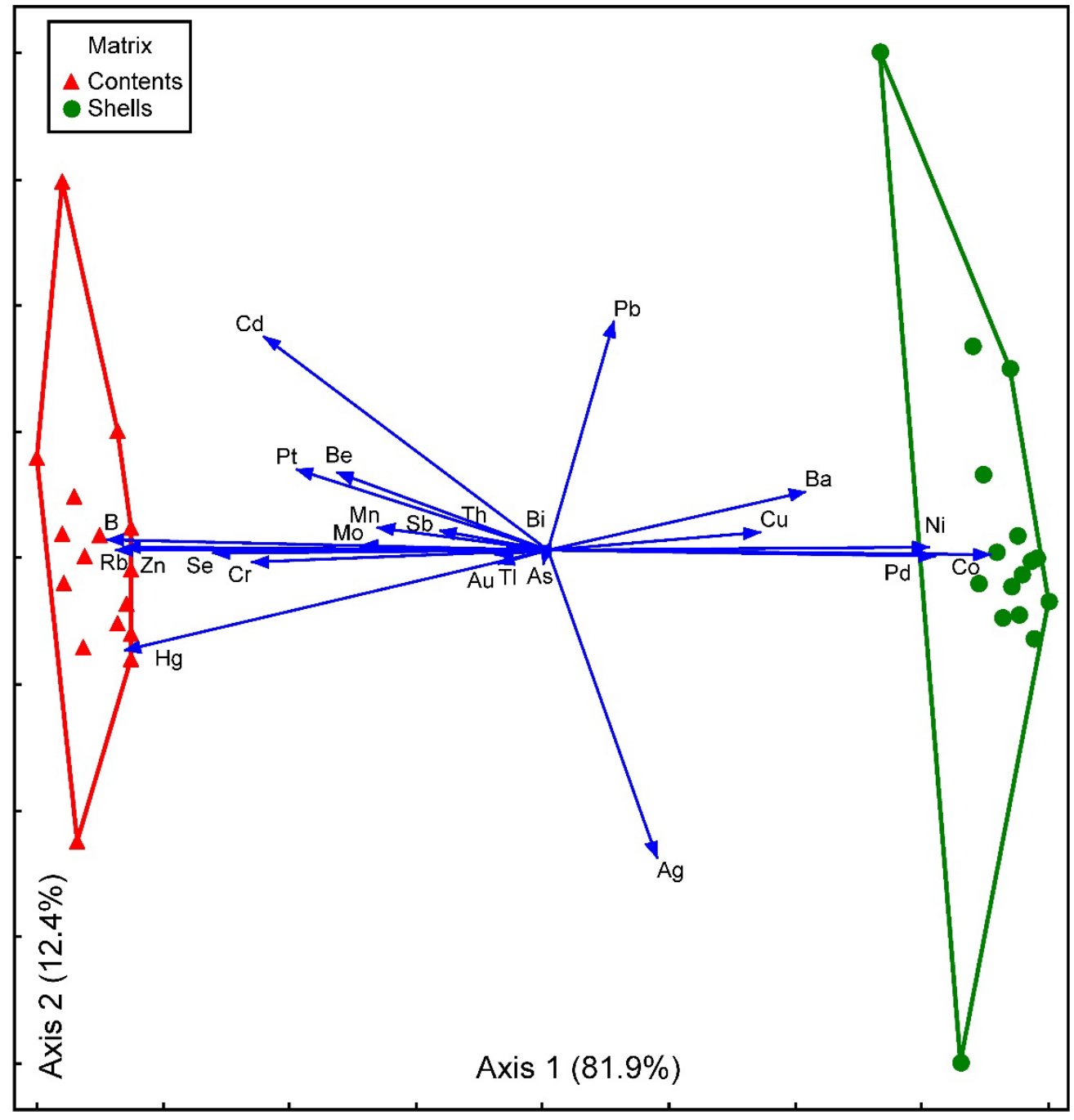

Figure 3: Nonmetric Multidimensional Scaling illustrating relative compositional profiles of metallic elements in Kelp Gull eggshells and egg contents with Sørenson as distance measure. Only two dimensions were needed, with a final stress of 6.15 reached after 49 iterations to achieve a final instability of 0.0000 . Axis 1 explained $81.9 \%$ of the variation, and axis 2 explained $12.4 \%$.

\section{Discussion}

\subsection{Elemental concentrations, comparisons with literature, and possible effects}

Chromium: Chromium is present naturally in the earth's crust and water, but elevated concentrations can be traced to anthropogenic activities (Mansouri et al., 2012b; Movalli, 2000). Concentrations of $\mathrm{Cr}$ can vary between 1 to $10 \mu \mathrm{g} / \mathrm{L}$ in river waters; in soil the concentrations can vary from 1 to $3000 \mathrm{mg} / \mathrm{kg}$ (Aslam \& Yousafzai; 2017). Chromium is 
associated with a wide variety of activities such as stainless steel welding, tanning, dyes and pigments, preservation of wood, sewage treatment, mining, and use in agriculture (Aslam \& Yousafzai, 2017; Egwumah et al., 2017; Mansouri et al., 2012b), all of which are present in the SE catchment.

Trivalent and hexavalent chromium are the two most abundant forms of $\mathrm{Cr}$ in the environment (Aslam \& Yousafzai, 2017). Trivalent chromium seems essential to at least some organisms for, inter alia, insulin regulation of carbohydrates, activation of specific enzymes, and the stabilisation of proteins (Pechova \& Pavlata, 2007; Simonetti et al., 2015; Živkov Baloš et al., 2016). However, hexavalent chromium can have neurological, respiratory, hepatic, and behavioural effects (Burger \& Elbin, 2015b; Wang et al., 2017) due to its ability to easily cross through biological membranes, impacting cell metabolism (Alijagic et al., 2018; Aslam \& Yousafzai, 2017). Furthermore, Wang et al. (2017) found that hexavalent chromium inhibits growth and reduce body mass of birds.

This study reports the highest $\mathrm{Cr}$ concentration found in literature for any larid egg or shell (Table 1). The high concentration coupled with the low \%CV would suggest physiological regulation on the one hand, but the high concentrations compared with the other larids (Table 1) suggests a possible environmental overload. Without knowledge of the valence of $\mathrm{Cr}$ in the environment and food of the Kelp Gull, no assessment of its toxicity can be made, but further investigation seems warranted based on the high concentrations found.

Zinc: Although an essential element, it can be toxic to birds when ingested in excess. As an essential element, $\mathrm{Zn}$ helps with metabolic processes and gene expression. Furthermore, Zn also plays a role in eggshell formation (Mansouri et al., 2012a ; Simonetti et al., 2015). Zinc is mainly released into the environment through mining and industrial effluent, but $\mathrm{Zn}$ can also be found in food packaging and transported via air. $\mathrm{Zn}$ is known to leach into water systems through leaking galvanized pipes from households (Klaassen \& Watkins, 2015; Nordberg et al., 2014). Furthermore, approximately half of the zinc that is transported by rivers is deposited in estuaries (Nordburg et al., 2014).

It is known that birds in general have some tolerance towards high concentrations of $\mathrm{Zn}$, but they may still be affected at elevated exposures (Mansouri et al., 2012a; Movalli, 2000; Yohannes et al., 2017). Although a high concentration of Zn was found within this study, it was not the highest concentrations yet reported for larid eggs (Table 1). Zinc may therefore be physiologically regulated as well as pose an ecotoxicological issue for larids in particular, and for aquatic animals in general, in the SE.

Strontium: Strontium is known to occur naturally within the environment as an inorganic element. The main input of Sr into the environment occurs from natural weathering of rocks and through atmospheric deposition (Kitowski et al., 2014). Even though chemically similar to $\mathrm{Ca}$, an increase in $\mathrm{Sr}$ can result in increased embryotoxicity affecting the transport 
of $\mathrm{Ca}$ and vitamin $\mathrm{D}$ resulting in lower hatching success, increased eggshell thinning, and shell breakage as Sr can cause physical changes of eggshells (Kitowski et al., 2014; Lam et al., 2005; Mora., 2003; Mora et al., 2007). An increase in Ca concentration will result in a decrease of Sr toxicity (Lam et al., 2005; McPherson et al., 2014). With little comparable information available from elsewhere, this is the second highest eggshell and egg content concentrations for gulls, with the highest concentration in Black-tailed Gull Larus crassirostris eggs from Japan (Table 1).

Despite the relatively low \%CV, the high concentrations we found suggests that $\mathrm{Sr}$ is occurring at elevated levels within the SE, but the specific source(s) are unknown. The Sr concentration within the eggshells was higher than the toxic reference value (TRV) determined by Meyer et al. (2015) for bird eggshells (between 360-1299 mg/kg dm). The egg content TRV (176-507 mg/kg dm) was not exceeded (Meyer et al., 2015).

Figure 2(h) illustrates a direct positive linear regression between $\mathrm{Ca}$ and $\mathrm{Sr}$ eggshell concentrations, suggesting interaction between these two elements. Strontium and $\mathrm{Ca}$ are divalent alkaline earth metals and mimic each other. Because of its atomic similarity to $\mathrm{Ca}$, Sr accumulates in milk and bone (Nordberg et al., 2015), as well as eggshells (du Preez et al., 2015). Although no clear evidence of eggshell thinning was seen (based on regressions; Section 3.2), there is still warrant for concern about Sr.

Vanadium: Vanadium occurs naturally in the environment, but is also anthropogenically added to the environment through fossil fuel burning (Nordberg et al., 2014). This element is physiologically essential, playing a role in bone formation, kidney development, and reproduction (Henry \& Miles, 2001; Metcheva et al., 2011). In low concentrations, $V$ does not display any toxic effects, but an increase can lead to inhibition of enzymes, decreased hatching success of birds, and lysis of cells (Henry \& Miles, 2001). Henry \& Miles (2001) found that when laying hens were fed with a concentration of $10 \mathrm{mg} / \mathrm{kg}$ $\checkmark$ in their food, kidney and bone development was impaired. They also determined a toxic threshold for $V$ between 8-50 mg/kg dm for egg contents. Živkov Baloš et al. (2016) reported that albumin quality and growth developments started to occur in poultry fed with concentrations of $6 \mathrm{mg} / \mathrm{kg} \mathrm{dm}$ feed and hatching success started to decrease from $40 \mathrm{mg} / \mathrm{kg}$ $\mathrm{dm}$ within feed. Although the concentrations of $\mathrm{V}$ in gull egg contents $(1 \mathrm{mg} / \mathrm{kg} \mathrm{dm}) \mathrm{did}$ not exceed those found by Henry \& Miles (2001) and Živkov Baloš et al. (2016), within egg content $\mathrm{V}$ concentrations warrants concern as they were higher than reported by others in literature for larid eggs (Table 1). This suggests elevated environmental levels, possibly from pollution.

Cobalt: Occurring naturally and in its oxidised form, Co forms complex associations with other metallic elements such as arsenic (As), Ni, copper (Cu), and iron (Fe) (DWAF, 1996; Gál et al., 2007; Gault et al., 2009). Cobalt is considered an essential element in 
animal metabolism, associated with the vitamin $B_{12}$ complex (Gál et al., 2007; Gault et al., 2009; Norouzi et al., 2012). Cobalt can enter the environment through natural processes but also through anthropogenic releases such as fossil fuel combustion, production of cobalt alloy, mining, burning of fossil fuels, and from refuse, sewage effluent, and agricultural runoff (Gál et al., 2007; Gault et al., 2009). All these sources are present at the SE.

At low concentrations, Co does not display any toxicity, but uptake of elevated concentrations can lead to DNA breakage, cardiomyopathy genotoxicity, reproductive defects, and mutagenicity (Gál et al., 2007; Gault et al., 2009). Although the egg content concentration was not the highest found in literature, the eggshell concentration was the highest centration based on literature (Table 1) for terns and gulls.

Uranium: Uranium is found within rocks and soil in its oxidised form. With a concentration of $0.0003 \%$ and $0.0004 \%$ in the earth's crust, relatively low concentrations occur naturally in fresh and marine water (Bleise et al., 2003; Boryło et al., 2010). Uranium has severe toxic effects for humans and animals, including developmental defects, nephrotoxicity, and genotoxicity (Brugge et al., 2011). The relatively low concentrations of $U$ combined with a relatively low \%CV in Kelp Gull eggs suggests that physiological regulation is taking place, but no concern about effects is not warranted.

Mercury: Mercury is one of the best-documented toxic elements in literature (Bond \& Lavers, 2011). It occurs naturally in the environment, but concentrations are increasing due to anthropogenic activities (Arcos et al., 2002). The transformation from inorganic to organic $\mathrm{Hg}$ is one of the major problems associated with $\mathrm{Hg}$ because methyl-mercury bioaccumulates in animals (Arcos et al., 2002). Mercury concentrations above $3 \mathrm{mg} / \mathrm{kg} \mathrm{dm}$ in animals can influence growth, embryonic development, hatching success, neurological, behaviour, and cause developmental defects (Burger \& Gochfeld, 2000, 2007; Mansouri, 2015; ; Yohannes et al., 2017). Seabirds seem to be more tolerant to higher $\mathrm{Hg}$ concentrations (Arcos et al., 2002; Burger \& Gochfeld, 2007). Meyer et al (2015) calculated the TRV for $\mathrm{Hg}$ at $2 \mathrm{mg} / \mathrm{kg} \mathrm{dm}$ in egg contents. Although the mean concentration of $\mathrm{Hg}$ did not exceed the TRV in eggs, one of the eggs had a concentration of $2.1 \mathrm{mg} / \mathrm{g} \mathrm{dm}$, therefore $\mathrm{Hg}$-associated toxicological effects might be expected in the SE.

\subsection{Trophic level increases}

Table 1 includes previous data from $\mathrm{Nel}$ et al. (2015) for sediment, mudprawn Upogebia Africana (Malacostraca: Upogebiidae), and three fish species; estuarine round herring Gilchristella aestuaria (Pisces: Clupeidae), Knysna sand goby Psammogobius knysnaensis (Pisces: Gobiidae), and the garrick Lichia amia (Pisces: Carangidae). 
The mud prawn is an important prey species for the Garrick, but the garrick is an unlikely prey species for gulls as it is quite large (up to $40 \mathrm{~cm}$ in length as used by Nel et al., 2015). However, when looking at the sediment - prawn - garrick trophic series (Table 1), Cr, $\mathrm{Co}, \mathrm{Cu}, \mathrm{Zn}, \mathrm{As}$, Se, and $\mathrm{Hg}$ increases in concentrations on a dry-mass basis. For the gull, the smaller estuarine round herring and Knysna sand goby (both about $7 \mathrm{~cm}$ in length) are important prey (Baird et al., 1988; Whitfield, 1998). When looking at the sediment - small fish - gull trophic series (Table 1), Zn, Se, and Hg, increases on a dry-mass basis. Because $\mathrm{Zn}$ and $\mathrm{Hg}$ increase in concentrations in the two SE food webs, they should be considered as elements of concern.

\subsection{Can the relative compositional profiles be used to compare eggshell and egg content?}

The NMS (Fig. 3) clearly shows differences in relative compositional profiles between egg contents and eggshells, as there was no overlap between their respective convex hulls. Relative higher proportions of rubidium ( $\mathrm{Rb}$ ), boron (B), $\mathrm{Zn}$ and $\mathrm{Hg}$ categorised egg contents, and higher relative proportions of $\mathrm{Co}$, palladium (Pd), and nickel ( $\mathrm{Ni}$ ) categorised eggshells (Fig. 3). Based on these results in combination with results presented in Table S1 and linear regressions (Fig. 2), Kelp Gull eggshells are not a viable proxy for egg content. Kelp Gull egg contents (and therefore the collection of whole eggs) will be needed to monitor embryonic exposures to metallic elements.

\subsection{Synthesis and conclusions}

Although the eggs were collected in 2012, we do not know of any major changes in the release of metallic elements since then that would substantially have affected current concentrations. We showed that $\mathrm{Hg}, \mathrm{Cr}, \mathrm{V}, \mathrm{Co}$, and $\mathrm{Zn}$ approached and exceeded concentrations from elsewhere and certain levels of concern where available. We therefore suggest further research into other higher trophic animals such as herons, egrets, cormorants, and otters, within the SE system, as well as identifying possible sources and mitigation measures to reduce pollution.

\section{Acknowledgements}

We would like to thank the National Research Foundation (NRF; Grant nr: 93977) for funding; any opinion, finding and conclusion or recommendation expressed in this article is that of the author(s) and the NRF does not accept any liability in this regard. We thank Mrs. Sabina Phillips who helped with the fieldwork. 


\section{References}

Agusa, T., Matsumoto, T., Ikemoto, T., Anana, Y., Kubota, R., Yasunaga, G., Kunito, T., Tanabe, S., Ogi, H., Shibata, R., 2005. Body distribution of trace elements in blacktailed gulls from Rishiri island, Japan: age dependent accumulation and transfer to feathers and eggs. Environ. Toxicol. Chem. 24, 2107-2120. https://doi.org/10.1897/04617R.1

Akearok, J.A., Hebert, C.E., Braune, B.M., Mallory, M.L., 2010. Inter- and intraclutch variation in egg mercury levels in marine bird species from the Canadian Arctic. Sci. Total Environ. 408, 836-840. https://doi.org/10.1016/j.scitotenv.2009.11.039

Aliakbari, A., Savabieasfahani, M. and Ghasempouri, S.M., 2011. Mercury in egg and eggshell of Whiskered Tern (Chlidonias hybrida) from Anzali wetlands of the Caspian Sea, Iran. Bull. Environ. Contam. Toxicol. 86, 175-179.

Alijagic, A., Islamagic, E., Focak, M., Suljevic, D., 2018. Effects of trivalent and hexavalent dietary chromium on blood biochemical profile in Japanese Quails. Bulg. J. Vet. Med. 21, 470-477. https://doi.org/10.15547/bjvm.1095

Arcos, J.M., Ruiz, X., Bearhop, S., Furness, R.W., 2002. Mercury levels in seabirds and their fish prey at the Ebro Delta (NW Mediterranean): The role of trawler discards as a source of contamination. Mar. Ecol. Prog. Ser. 232, 281-290. https://doi.org/10.3354/meps232281

Aslam, S., Yousafzai, A.M., 2017. Chromium toxicity in fish: A review article. $\sim 1483 \sim$ J. Entomol. Zool. Stud. 5, 1483-1488.

ATSDR (Agency for Toxic Substances and Disease Registry), 2017. Priority list of hazardous substances. http://www.atsdr.cdc.gov/SPL/index.html (Last accessed: 14/12/18).

Avazpour, F.G., Bakhtiari, A.R., Sajjadi, M.M., 2014. Levels of vanadium in tern eggs and sediments of Shidvar and Bani Farour Islands, Persian Gulf 9.

Ayaş, Z., 2007. Trace element residues in eggshells of Grey Heron (Ardea cinerea) and Black-crowned Night Heron (Nycticorax nycticorax) from Nallihan Bird Paradise, Ankara-Turkey. Ecotoxicology 16, 347-352. https://doi.org/10.1007/s10646-007-0132-6

Baird, D., Marias, J.F.K., Martin, A.P., 1988. The Swartkops Estuary: Proceedings of a symposium held on 14 and 15 September 1987 at the University of Port Elizabeth. South African National Scientific Programmes Rep. No 156CSIR, Pretoria. South Africa.

Binning, K., Baird, D., 2001. Survey of heavy metals in the sediments of the Swartkops River Estuary, Port Elizabeth South Africa. Water SA 27, 461-466. https://doi.org/10.4314/wsa.v27i4.4958

Bleise, A., Danesi, P.R., Burkart, W., 2003. Properties, use and health effects of depleted 
uranium (DU): a general overview. J. Environ. Radioact. 64, 93-112.

Bond, A.L., Lavers, J.L., 2011. Trace element concentrations in feathers of Flesh-footed Shearwaters (Puffinus carneipes) from across their breeding range. Arch. Environ. Contam. Toxicol. 61, 318-326. https://doi.org/10.1007/s00244-010-9605-3

Boryło, A., Skwarzec, B., Fabisiak, J., 2010. Bioaccumulation of uranium 234U and 238U in marine birds. J. Radioanal. Nucl. Chem. 284, 165-172. https://doi.org/10.1007/s10967010-0462-3

Brugge, D., Buchner, V., 2011. Health effects of uranium: new research findings. Rev. Environ. Heal. https://doi.org/10.1515/REVEH.2011.032

Burger, J., 2002. Food chain differences affect heavy metals in bird eggs in Barnegat Bay, New Jersey. Environ. Res. 90, 33-39. https://doi.org/10.1006/enrs.2002.4381

Burger, J., Elbin, S., 2015a. Contaminant levels in Herring (Larus argentatus) and Great Black-backed Gull (Larus marinus) eggs from colonies in the New York Harbor complex between 2012 and 2013. Ecotoxicology 24, 445-452. https://doi.org/10.1007/s10646014-1393-5

Burger, J., Elbin, S., 2015b. Metal levels in eggs of waterbirds in the New York Harbor (USA): Trophic relationships and possible risk to human consumers. J. Toxicol. Environ. Heal. - Part A Curr. Issues 78, 78-91. https://doi.org/10.1080/15287394.2014.941965

Burger, J., Gochfeld, M., 2000. Metal levels in feather of 12 species of seabirds from Midway Atoll in the northern Pacific Ocean. Sci. Total Environ. 257, 37-52.

Burger, J., Gochfeld, M., 2003. Spatial and temporal patterns in metal levels in eggs of Common Terns (Sterna hirundo) in New Jersey. Sci. Total Environ. 311, 91-100. https://doi.org/10.1016/S0048-9697(03)00135-9

Burger, J., Gochfeld, M., 2007. Metals and radionuclides in birds and eggs from Amchitka and Kiska Islands in the Bering Sea/Pacific Ocean ecosystem. Environ. Monit. Assess. 127, 105-117. https://doi.org/10.1007/s10661-006-9264-z

Burger, J., Gochfeld, M., Jeitner, C., Burke, S., Volz, C.D., Snigaroff, R., Snigaroff, D., Shukla, T., Shukla, S., 2009. Mercury and other metals in eggs and feathers of Glaucous-winged Gulls (Larus glaucescens) in the Aleutians. Environ. Monit. Assess. 152, 179-194. https://doi.org/10.1007/s10661-008-0306-6

Crawford, R.J.M., Cooper, J., Shelton, P.A., 1982. Distribution, population size, breeding and conservation of the Kelp Gull in Southern Africa. Ostrich 53, 164-177. https://doi.org/10.1080/00306525.1982.9634747

Crawford, R.J.M., Nel, D.C., Williams, A.J., Scott, A., 1997. Seasonal patterns of abundance of Kelp Gulls Larus dominicanus at breeding and non-breeding localities in southern Africa. Ostrich 68, 37-41. https://doi.org/10.1080/00306525.1997.9633979 
Dauwe, T., Bervoets, L., Blust, R., Pinxten, R., Eens, M., 1999. Are eggshells and egg contents of great and blue tits suitable as indicators of heavy metals pollution? Belgian J. Zoo., 129, pp.439-447.

DWAF., 1996. Department of Water Affairs and Forestry, 1996. South African Water Quality Guidelines. Volume 4. Agricultural Use: Irrigation, Water.

Eggleton, J., Thomas, K. V., 2004. A review of factors affecting the release and bioavailability of contaminants during sediment disturbance events. Environ. Int. 30, 973-980. https://doi.org/10.1016/j.envint.2004.03.001

Egwumah, F., Egwumah, P., Tyowua, B., 2017. An Investigation of chromium toxicity in the wild population of Black-Headed Oriole Oriolus brachyrhynchus (Swainson, 1837) using atomic absorption spectrometry (AAS). Int. J. Avian Wildl. Biol. 2, 2-7. https://doi.org/10.15406/ijawb.2017.02.00031

Gál, J., Hursthouse, A., Tatner, P., Stewart, F., Welton, R., 2008. Cobalt and secondary poisoning in the terrestrial food chain: Data review and research gaps to support risk assessment. Environ. Int. 34, 821-838. https://doi.org/10.1016/j.envint.2007.10.006

Gault, N., Sandre, C., Poncy, J.L., Moulin, C., Lefaix, J.L., Bresson, C., 2010. Cobalt toxicity: Chemical and radiological combined effects on HaCaT keratinocyte cell line. Toxicol. Vitr. 24, 92-98. https://doi.org/10.1016/j.tiv.2009.08.027

Grajewska, A., Falkowska, L., Szumiło-Pilarska, E., Hajdrych, J., Szubska, M., Frączek, T., Meissner, W., Bzoma, S., Bełdowska, M., Przystalski, A., Brauze, T., 2015. Mercury in the eggs of aquatic birds from the Gulf of Gdansk and Wloclawek Dam (Poland). Environ. Sci. Pollut. Res. 22, 9889-9898. https://doi.org/10.1007/s11356-015-4154-y Hashmi, M.Z., Abbasi, N.A., Tang, X., \& Malik, R.N. 2015. Egg as a biomonitor of heavy metals in soil: In, Sherameti, I., Varma, A. (eds.), Heavy metal contamination of soils: Monitoring and remediation. Springer International Publishing. 44; 127-143.

Henry, P.R., Miles, R., 2001. Heavy Metals - Vanadium in poultry. Ciência Anim. Bras. 2, 11-26.

Hockey P.A.R., Dean, W.R.J., Ryan, P.G., (eds). 2005. Roberts - Birds of Southern Africa, VII ${ }^{\text {th }}$ ed. The trustees of the John Voelcker Bird Book Fund, Cape Town.

IUCN., 2016. Bird Life International. Larus dominicanus. The IUCN Red List of Threatened Species 2016: e.T22694329A93448691. http://dx.doi.org/10.2305/IUCN.UK.20163.RLTS.T22694329A93448691.en.

Klaassen, C.D., Watkins, J.B.I.I.I., 2015. Casarett \& Doull's essentials of toxicology. New York: McGraw-Hill Medical, [2015].

Khademi, N., Riyahi-Bakhtiari, A., Sobhanardakani, S., Rezaie-Atagholipour, M., Burger, J., 2015. Developing a bioindicator in the Northwestern Persian Gulf, Iran: Trace elements in bird eggs and in coastal sediments. Arch. Environ. Contam. Toxicol. 68, 274-282. 
https://doi.org/10.1007/s00244-014-0084-9

Kim, J., Oh, J.M., 2014. Trace element concentrations in eggshells and egg contents of Black-tailed Gull (Larus crassirostris) from Korea. Ecotoxicology 23, 1147-1152. https://doi.org/10.1007/s10646-014-1256-0

Kitowski, I., Sujak, A., Wiaçek, D., Strobel, W., Rymarz, M., 2014. Trace element residues in eggshells of Grey Heron (Ardea cinerea) from colonies of East Poland. North. West. J. Zool. 10, 346-354. https://doi.org/10.1080/21658005.2013.817518

Lam, J.C.W., Tanabe, S., Lam, M.H.W., Lam, P.K.S., 2005. Risk to breeding success of waterbirds by contaminants in Hong Kong: Evidence from trace elements in eggs. Environ. Pollut. 135, 481-490. https://doi.org/10.1016/j.envpol.2004.11.021

Lord, D.A., Thompson, G.A., 1988. The Swartkops estuary: pollution status, in: Baird, D., Martais, J.F.K., Martin, A.P. (eds.), Proceedings of a symposium held on the $14^{\text {th }}$ and 15 $5^{\text {th }}$ September 1987. University of Port Elizabeth. pp. 16-24.

Mansouri, B., Babaei, H., Hoshyari, E., 2012a. Heavy metal contamination in feathers of Western Reef Heron (Egretta gularis) and Siberian gull (Larus heuglini) from Hara Biosphere Reserve of Southern Iran. Environ. Monit. Assess. 184, 6139-6145. https://doi.org/10.1007/s10661-011-2408-9

Mansouri, B., Pourkhabbaz, A., Babaei, H., Hoshyari, E., Khodaparast, S.H., Mirzajani, A., 2012b. Assessment of trace-metal concentrations in Western Reef Heron (Egretta gularis) and Siberian Gull (Larus heuglini) from Southern Iran. Arch. Environ. Contam. Toxicol. 63, 280-287. https://doi.org/10.1007/s00244-012-9779-y

Martin, A.P., Baird, D., 1987. Seasonal abundance and distribution of birds on the Swartkops Estuary, Port Elizabeth. Ostrich 58, 37-41. https://doi.org/10.1080/00306525.1987.9633685

Martin, A.P., Randall, R.M., 1987. Numbers of waterbirds at a commercial saltpan, and suggestions for management. South African J. Wildl. Res. 17, 75-81.

McCune, B., Grace, J.B., Urban, D.L., 2002. Analysis of ecological communities. MjM software design Gleneden Beach, OR.

McPherson, C.A., Lawrence, G.S., Elphick, J.R., Chapman, P.M., 2014. Development of a strontium chronic effects benchmark for aquatic life in freshwater. Environ. Toxicol. Chem. 33, 2472-2478. https://doi.org/10.1002/etc.2696

Metcheva, R., Yurukova, L., Teodorova, S.E., 2011. Biogenic and toxic elements in feathers, eggs, and excreta of Gentoo Penguin (Pygoscelis papua ellsworthii) in the Antarctic. Environ. Monit. Assess. 182, 571-585. https://doi.org/10.1007/s10661-011-1898-9 Meyer, C.B., Schlekat, T.H., Walls, S.J., Iannuzzi, J., Souza, M.J., 2015. Evaluating risks to wildlife from coal fly ash incorporating recent advances in metals and metalloids risk assessment. Integr. Environ. Assess. Manag. 11, 67-79. 
https://doi.org/10.1002/ieam.1576

Mora, M.A., 2003. Heavy metals and metalloids in egg contents and eggshells of passerine birds from Arizona. Environ. Pollut. 125, 393-400. https://doi.org/10.1016/S02697491(03)00108-8

Mora, M.A., Taylor, R.J., Brattin, B.L., 2007. Potential ecotoxicological significance of elevated concentrations of strontium in eggshells of passerine birds. Condor 109, 199205. https://doi.org/10.1650/0010-5422(2007)109[199:PESOEC]2.0.CO;2

Movalli, P.A., 2000. Heavy metal and other residues in feathers of laggar Falcon Falco biarmicus jugger from six districts of Pakistan. Environ. Pollut. 109, 267-275. https://doi.org/10.1016/S0269-7491(99)00258-4

Nel, L., Strydom, N.A., Bouwman, H., 2015. Preliminary assessment of contaminants in the sediment and organisms of the Swartkops Estuary, South Africa. Mar. Pollut. Bull. 101, 878-885. https://doi.org/10.1016/j.marpolbul.2015.11.015

Nordberg, G.F., Fowler, B.A., Nordberg, M., 2014. Handbook on the toxicology of metals, 4th ed. Academic press.

Norouzi, M., Mansouri, B., Hamidian, A.H., Ebrahimi, T., Kardoni, F., 2012. Comparison of the metal concentrations in the feathers of three bird species from Southern Iran. Bull. Environ. Contam. Toxicol. 89, 1082-1086. https://doi.org/10.1007/s00128-012-0798-1

Odume, O.N., 2015. An evaluation of macroinvertebrate-based biomonitoring and ecotoxicological assessments of deteriorating environmental water quality in the Swartkops River, South Africa. 373.

Pechova, A., Pavlata, L., 2007. Chromium as an essential nutrient: A review. Vet. Med. (Praha). 52, 1-18. https://doi.org/10.17221/2010-VETMED

Peck, L.E., Gilchrist, H.G., Mallory, C.D., Braune, B.M., Mallory, M.L., 2016. Persistent organic pollutant and mercury concentrations in eggs of ground-nesting marine birds in the Canadian high Arctic. Sci. Total Environ. 556, 80-88.

https://doi.org/10.1016/j.scitotenv.2016.02.205

Pizzol, M., Christensen, P., Schmidt, J., Thomsen, M., 2011. Eco-toxicological impact of "metals" on the aquatic and terrestrial ecosystem: A comparison between eight different methodologies for life cycle impact assessment (LCIA). J. Clean. Prod. 19, 687-698. https://doi.org/10.1016/j.jclepro.2010.12.008

Quinn, L.P., 2010. Assessment of organic pollutants in selected wild and domesticated bird eggs from Gauteng, South Africa. North-West University, Potchefstroom Campus.

Sepúlveda, M., Gonzalez-Acuña, D., 2014. Comparison of heavy metals from resident Larus dominicanus and migratory Leucophaeus pipixcan collected in Talcahuano, Chile. Arch. Med. Vet. 46, 299-304. https://doi.org/10.4067/S0301-732X2014000200016

Simonetti, P., Botté, S.E., Marcovecchio, J.E., 2015. Exceptionally high Cd levels and other 
trace elements in eggshells of American oystercatcher (Haematopus palliatus) from the Bahía Blanca Estuary, Argentina. Mar. Pollut. Bull. 100, 495-500.

https://doi.org/10.1016/j.marpolbul.2015.09.006

Suiçmez, M., Kayim, M., Köseoğlu, D., Hasdemir, E., 2006. Toxic effects of lead on the liver and gills of Oncorhynchus mykiss WALBAUM 1792. Bull. Environ. Contam. Toxicol. 77, 551-558. https://doi.org/10.1007/s00128-006-1099-3

UN Environment. (2018). Tackling global water pollution. [online] Available at:

https://www.unenvironment.org/explore-topics/water/what-we-do/tackling-global-waterpollution [Accessed 14 Dec. 2018].

Wallace, J.H., Kok, H.M., Beckley, L.E., Bennett, B., Blaber, S.J.M., Whitfield, A.K., 1984.

South African estuaries and their importance to fishes. S. Afr. J. Sci. 80, 203-207.

Wang, Y., Liu, Y., Wan, H., Zhu, Y., Chen, P., Hao, P., Cheng, Z., Liu, J., 2017. Moderate selenium dosing inhibited chromium (VI) toxicity in chicken liver. J. Biochem. Mol. Toxicol. 31. https://doi.org/10.1002/jbt.21916

Whitfield, A.K., 1998. Biology and ecology of fishes in Southern African estuaries. Ichthyological Monographs of the J.L.B Smith Institute of Ichthyology 2. 223 pp.

Whittington, P.A., Crawford, R.J., Martin, A.P., Randall, R.M., Brown, M., Ryan, P.G., Dyer, B.M., Harrison, K.H.B., Huisamen, J., Makhado, A.B., Upfold, L., Waller, L.J., Witteveen, M., 2016. Recent trends of the Kelp Gull (Larus dominicanus) in South Africa. Waterbirds 39, 99-113. https://doi.org/10.1675/063.039.sp102

Whittington, P.A., Paul Martin, A., Klages, N.T.W., Schultz, A., 2009. Movements of the Kelp Gull Larus dominicanus vetula to, from and within southern South Africa. Mar. Ornithol. 37, 139-152.

Yohannes, Y.B., Ikenaka, Y., Nakayama, S.M.M., Mizukawa, H., Ishizuka, M., 2017. Trace element contamination in tissues of four bird species from the Rift Valley Region, Ethiopia. Bull. Environ. Contam. Toxicol. 98, 172-177. https://doi.org/10.1007/s00128016-2011-4

Živkov Baloš, M., Ljubojević, D., Jakšić, S., 2016. The role and importance of vanadium, chromium and nickel in poultry diet. Worlds. Poult. Sci. J. 73, 5-16.

https://doi.org/10.1017/S0043933916000842 


\section{Comparing the metallic elemental compositions of Kelp Gull Larus dominicanus eggs}

and eggshells from the Swartkops Estuary, Port Elizabeth, South Africa

J.D. van Aswegen ${ }^{a}$, L. Nelela, , N.A. Strydom ${ }^{b}$, K. Minnaar ${ }^{a}$, H. Kylin ${ }^{a, c}$, H. Bouwman ${ }^{a}$

a Research Unit: Environmental Sciences and Management, North-West University, Potchefstroom, South Africa

${ }^{b}$ Department of Zoology, Nelson Mandela University, Port Elizabeth, South Africa

c Department of Thematic Studies - Environmental Change, Linköping University, Linköping,

Sweden.

Supplemental materials

Table S1: Concentrations in eggshells and egg content for 30 elements ( $\mathrm{mg} / \mathrm{kg} \mathrm{dm}$ ).

\begin{tabular}{|c|c|c|c|c|c|c|c|c|c|c|c|c|c|c|}
\hline & \multicolumn{7}{|c|}{ Shells } & \multicolumn{7}{|c|}{ Egg content } \\
\hline Element & $n$ & Mean & Median & Min & $\operatorname{Max}$ & SD & $\% \mathrm{CV}$ & $n$ & Mean & Median & Min & Max & SD & $\% \mathrm{CV}$ \\
\hline $\mathrm{Be}$ & 16 & 0.00013 & 0.000009 & 0.0000007 & 0.0012 & 0.00034 & $260 \%$ & 16 & 0.00032 & 0.000034 & 0.000002 & 0.0017 & 0.00048 & $150 \%$ \\
\hline B & 16 & 0.018 & 0.02 & 0.003 & 0.029 & 0.0083 & $46 \%$ & 16 & 1 & 1 & 1 & 2 & 0.42 & $34 \%$ \\
\hline Al & 16 & 18 & 14 & 5 & 61 & 17 & $89 \%$ & 16 & 3 & 3 & 2.5 & 6 & 1 & $26 \%$ \\
\hline $\mathrm{Ti}$ & 16 & 77 & 730 & 480 & 1100 & 200 & $27 \%$ & 16 & 11 & 11 & 10 & 13 & 1 & $6 \%$ \\
\hline V & 16 & 170 & 170 & 110 & 246 & 32 & $19 \%$ & 16 & 1 & 1 & 0.95 & 1.5 & 0.1455 & $11 \%$ \\
\hline $\mathrm{Cr}$ & 16 & 4 & 3.5 & 0.17 & 6 & 2 & $42 \%$ & 16 & 18 & 19 & 15 & 20 & 1.5 & $8 \%$ \\
\hline Mn & 16 & 0.7 & 0.5 & 0.23 & 1.5 & 0.42 & $62 \%$ & 16 & 2 & 1 & 1 & 2.5 & 0.44 & $31 \%$ \\
\hline $\mathrm{Fe}$ & 16 & 840 & 840 & 770 & 900 & 43 & $5 \%$ & 16 & 101 & 105 & 63 & 140 & 21 & $21 \%$ \\
\hline Co & 16 & 2 & 2 & 1 & 2 & 0.14 & $8 \%$ & 16 & 0.02 & 0.02 & 0.01 & 0.028 & 0.0043 & $23 \%$ \\
\hline $\mathrm{Ni}$ & 16 & 1.4 & 1.4 & 1.3 & 2 & 0.09 & $6 \%$ & 16 & 0.12 & 0.11 & 0.08 & 0.27 & 0.06 & $47 \%$ \\
\hline $\mathrm{Cu}$ & 16 & 13 & 12 & 8 & 21 & 4 & $32 \%$ & 16 & 5 & 3.5 & 3 & 24 & 5 & $110 \%$ \\
\hline$Z n$ & 16 & 2.1 & 2 & 0.45 & 5 & 1 & $50 \%$ & 16 & 62 & 63 & 47 & 75 & 7 & $12 \%$ \\
\hline As & 16 & 0.3 & 0.3 & 0.08 & 0.35 & 0.078 & $30 \%$ & 16 & 0.26 & 0.25 & 0.1 & 0.45 & 0.1 & $40 \%$ \\
\hline Se & 16 & 0.3 & 0.3 & 0.09 & 0.58 & 0.13 & $43 \%$ & 16 & 2 & 2 & 1.4 & 3 & 0.47 & $24 \%$ \\
\hline $\mathbf{R b}$ & 16 & 0.1 & 0.07 & 0.05 & 0.17 & 0.037 & $44 \%$ & 16 & 4 & 4 & 3 & 5 & 1 & $20 \%$ \\
\hline $\mathrm{Sr}$ & 16 & 880 & 960 & 360 & 1300 & 290 & $33 \%$ & 16 & 12 & 11 & 8 & 17 & 3 & $24 \%$ \\
\hline Mo & 16 & 0.1 & 0.11 & 0.09 & 0.13 & 0.012 & $11 \%$ & 16 & 0.25 & 0.25 & 0.19 & 0.3 & 0.03 & $13 \%$ \\
\hline Pd & 16 & 3 & 3 & 2 & 4 & 0.69 & $23 \%$ & 16 & 0.22 & 0.2 & 0.17 & 0.35 & 0.05 & $24 \%$ \\
\hline$\overline{A g}$ & 16 & 0.5 & 0.03 & 0.00028 & 7 & 2 & $350 \%$ & 16 & 0.28 & 0.21 & 0.0017 & 1 & 0.3 & $98 \%$ \\
\hline Cd & 16 & 0.0004 & 0.000013 & 0.00000084 & 0.0018 & 0.00065 & $160 \%$ & 16 & 0.0015 & 0.00044 & 0.0000022 & 0.015 & 0.004 & $250 \%$ \\
\hline Sb & 16 & 0.03 & 0.03 & 0.03 & 0.042 & 0.0049 & $15 \%$ & 16 & 0.051 & 0.035 & 0.029 & 0.23 & 0.049 & $97 \%$ \\
\hline $\mathrm{Ba}$ & 16 & 5 & 4 & 2 & 10 & 2 & $47 \%$ & 16 & 1 & 2 & 0.45 & 2 & 0.42 & $30 \%$ \\
\hline $\mathrm{Pt}$ & 16 & 0.01 & 0.003 & 0.00036 & 0.186 & 0.046 & $310 \%$ & 16 & 0.041 & 0.028 & 0.0049 & 0.12 & 0.034 & $84 \%$ \\
\hline $\mathrm{Au}$ & 16 & 0.3 & 0.2 & 0.24 & 0.38 & 0.038 & $15 \%$ & 16 & 0.32 & 0.26 & 0.24 & 0.73 & 0.12 & $40 \%$ \\
\hline $\mathrm{Hg}$ & 16 & 0.02 & 0.0001 & 0 & 0.13 & 0.039 & $270 \%$ & 16 & 0.4 & 0.2 & 0.1 & 2 & 0.49 & $130 \%$ \\
\hline $\mathrm{TI}$ & 16 & 0.0002 & 0.0002 & 0.00008 & 0.00022 & 0.000046 & $27 \%$ & 16 & 0.00022 & 0.00022 & 0.00019 & 0.00023 & 0.000013 & $6 \%$ \\
\hline $\mathbf{P b}$ & 16 & 0.02 & 0.0008 & 0.00009 & 0.17 & 0.045 & $210 \%$ & 16 & 0.014 & 0.0008 & 0.0004 & 0.1 & 0.026 & $188 \%$ \\
\hline $\mathrm{Bi}$ & 16 & 0.09 & 0.08 & 0.08 & 0.085 & 0.00059 & $1 \%$ & 16 & 0.089 & 0.085 & 0.084 & 0.13 & 0.011 & $13 \%$ \\
\hline Th & 16 & 0.2 & 0.16 & 0.15 & 0.16 & 0.0026 & $2 \%$ & 16 & 0.2 & 0.2 & 0.16 & 0.35 & 0.046 & $25 \%$ \\
\hline U & 16 & 0.00006 & 0.00006 & 0.000024 & 0.00008 & 0.000018 & $31 \%$ & 16 & 0.000084 & 0.000085 & 0.00007 & 0.000095 & 0.0000072 & $9 \%$ \\
\hline
\end{tabular}

